\title{
Pengelolaan Sarana dan Prasarana Olahraga
}

\section{Management of Sports Facilities and Infrastructure}

\author{
Achmad Gunawan'1, Ika Rudi Mahendra², Abdurrahim Hidayat ${ }^{3}$
}

1,2,3 Kementerian Koordinator Bidang Pembangunan Manusia dan Kebudayaan

\section{Penulis Korespondensi}

Achmad Gunawan achmad.gunawan91@ui.ac.id +628117871104

\begin{abstract}
Abstrak
Sarana dan prasarana olahraga tidak terkelola dengan baik, sehingga menghambat upaya peningkatan prestasi olahraga dan pembudayaan olahraga secara luas. Perlu dilihat secara mendalam apa penyebab tidak terkelolanya dengan baik sarana dan prasarana olahraga tersebut, sebagai dasar pertimbangan kebijakan pengelolaan ke depan. Untuk itu, penelitian ini bertujuan untuk melihat lebih dalam terhadap persoalan pengelolaan sarana dan prasarana olahraga di Indonesia. Penelitian ini adalah penelitian studi kasus pada venue olahraga di lima Provinsi, yaitu: Riau, Sumsel, Jawa Barat, Kaltim, dan DKI Jakarta, yang memang merupakan pusat-pusat sarana dan prasarana terbesar yang ada di Indonesia. Analisisnya menggunakan kerangka kerja Schwarz et al. sebagai landasan teori, kemudian dilengkapi dengan kerangka praktis dari prinsip-prinsip pembangunan sarana dan prasarana olahraga di Australia, dan kerangka kerja pembangunan sarana dan prasarana olahraga di New Zealand. Metode yang digunakan adalah metode kualitatif karena berupaya menjawab pertanyaan bagaimana pengelolaan sarana dan prasarana olahraga. Datanya adalah data sekunder hasil monitoring dan evaluasi ke lapangan, serta dokumen-dokumen terkait lainnya. Dengan menyandingkan beberapa persoalan dari masing-masing provinsi, peneliti berharap mendapatkan letak persoalan sesungguhnya. Di akhir dapat ditemukan bahwa tidak ada pertimbangan jauh ke depan terkait pembangunan sarana dan prasarana olahraga, tidak ada kaitan budaya olahraga masyarakat dengan ketersediaan sarana dan prasarana, dan tidak ada kaitan antara ketersediaan sarana dan prasarana dengan prestasi olahraga provinsi di mana pusat sarana dan prasarana berada. Oleh karena itu dapat disimpulkan bahwa persoalan tidak terawatnya prasarana dan sarana dan pemanfaatan yang tidak optimal lebih disebabkan pada perencanaan pembangunan sarana dan prasarana yang tidak komprehensif dengan memperhatikan budaya olahraga masyarakat setempat, potensi pergerakan event olahraga, dan keterpaduan dengan bidang lainnya seperti aksesibilitas, pariwisata, dan layanan masyarakat lainnya.
\end{abstract}

\section{Kata Kunci}

olahraga; sarana dan prasarana; manajemen

\begin{abstract}
Sports facilities that are not well managed could hamper the efforts to increase sports achievement and broaden sports culture. It needs an in-depth overview of what causes the sports facilities are not properly managed, as a basis for future management policy considerations. Applying case studies at sports venues in five provinces, including Riau, South Sumatra, West Java, East Kalimantan, and DKI Jakarta, this research aims to delve deeper into the problem of managing sports facilities. The framework concept of Schwarz et al. is used as a theoretical foundation, which is then supplemented by a practical framework based on the concepts of the sports facility growth in Australia, as well as a framework for sport facility development in New Zealand. The researcher uses a qualitative approach because it seeks the answer of how to manage sport facilities. The data are secondary data from monitoring and assessing the outcomes in the field, as well as other related documents. The researcher hopes to figure out the real problem by juxtaposing multiple problems from each province. Thus, it can be found that there are no further considerations regarding the development of sports facilities, there is no connection with the sports culture of the community with the availability of facilities, and there is no link between the availability of facilities with the provincial sports achievements where the center of facilities is located. For the conclusion, it was discovered that the issue of poorly maintained facilities and inadequate utilization, is due to insufficient planning for the development of facilities by paying attention to the sports culture of the local community, the potential for sports event movements, and integration with other fields such as accessibility, tourism, and other community services.
\end{abstract}

\section{Keywords}

sport; facility; management 


\section{Pendahuluan}

Human Development Index (HDI) atau Indeks Pembangunan Manusia (IPM) terdiri dari 3 indikator dasar, yaitu: kesehatan, pendidikan, dan ekonomi. Secara sempit olahraga memang hanya terkait dengan indikator kesehatan, namun dalam konteks yang luas olahraga bisa mencakup ketiganya. Meskipun harus diteliti lebih jauh, namun olahraga telah dianggap memiliki kekuatan besar dalam pembangunan ekonomi secara umum (Levermore, 2015, hal. 55-66). Lebih jauh lagi, olahraga juga memiliki sifat integratif dari aspek politik, bahkan dapat dengan dramatis terikat dengan hubungan internasional (Frey \& Eitzen, 1991, hal. 503-522). Dalam upaya pembangunan manusia, pembangunan keolahragaan merupakan bagian integral dari pembangunan nasional, melalui peningkatan kesehatan jasmani, kualitas mental rohani masyarakat, pembentukan karakter bangsa, disiplin dan sportivitas, serta prestasi untuk kebanggaan (Kristiyanto, 2012).

Sarana dan prasarana olahraga adalah salah satu hal paling penting dalam keolahragaan. Baik pada pembinaan prestasi olahraga maupun pada pengembangan olahraga rekreasi di masyarakat. Terdapat hubungan yang positif antara ketersediaan sarana dan prasarana olahraga dengan perilaku hidup sehat (Kurniantyo, 2015, hal. 1832-1838). Sarana dan prasarana olahraga juga berpengaruh secara signifikan terhadap kesegaran jasmani (Sujana, 2018, hal. 1689-1699). Partisipasi masyarakat dalam kegiatan olahraga dan rekreasi memberikan dampak positif terhadap keseimbangan hidup yang sehat, dan dalam skala luas dapat mendorong pembangunan ekonomi (Goslin et al., 2015).

Tanpa sarana dan prasarana yang memadai sangat sulit menciptakan atlet yang mampu berprestasi di tingkat internasional, yang saat ini persaingannya sudah lebih banyak berada pada aspek sport science. Tanpa sarana dan prasarana yang memadai, sulit untuk menciptakan masyarakat yang gemar berolahraga, yang dapat mendorong terciptanya generasi yang sehat dan bugar. Lebih tegas lagi, sarana dan prasarana adalah kunci sukses pembangunan olahraga suatu negara (Rismayanthi, 2007, hal. 1-12).

Sarana dan prasarana olahraga adalah suatu alat dan bangunan yang dirancang sesuai dengan persyaratan tertentu untuk melakukan suatu kegiatan olahraga tertentu (Mulyo et al., 2014, hal. 1-11). Di Undang-Undang Nomor 3 Tahun 2005 tentang Sistem Keolahragaan Nasional, definisi sarana dan prasarana tidak terlalu berbeda, yaitu di mana di dalamnya terdapat unsur ruang atau lingkungan dan peralatan serta perlengkapan yang digunakan untuk kegiatan olahraga. Sarana dan prasarana sering kali disebut bersamaan, karena memang pada dasarnya merupakan kesatuan yang tidak dapat dipisahkan sebagai fasilitas olahraga.

Dalam RPJMN 2020-2024 khususnya pada Prioritas Pembangunan Nasional: "Meningkatkan SDM yang Berkualitas dan Berdaya Saing”, di dalamnya termaktub Kegiatan prioritas: "Peningkatan Prestasi Olahraga" yang terdiri dari beberapa Proyek Prioritas, di mana salah satu di antaranya adalah: "Peningkatan Sarana dan Prasarana Olahraga Berstandar Internasional”. Fakta ini menunjukkan adanya komitmen dan kesadaran tentang pentingnya penyediaan sarana dan prasarana olahraga yang memadai bagi pembangunan secara umum.

Indonesia memiliki beberapa sport center yang tersebar di beberapa provinsi yang pada awalnya dibangun dalam rangka penyelenggaraan event olahraga nasional dan internasional. Di antaranya yang terlengkap adalah kompleks olahraga Gelora Bung Karno yang dibangun untuk Asian Games 1962, yang saat ini terdiri dari 12 venue olahraga. Kemudian kompleks olahraga Jakabaring Palembang yang dibangun untuk PON 2004, yang saat ini terdiri dari 15 venue olahraga, Stadion Utama Riau yang dibangun untuk PON 2012, kompleks olahraga Arcamanik - Bandung yang mulai digunakan tahun 2017 terdiri dari 7 venue olahraga, dan kompleks olahraga Stadion Utama Palaran dan Stadion Madya Sempaja Samarinda yang dibangun untuk PON 2008. Selain kompleks olahraga tersebut Indonesia juga masih banyak memiliki sarana dan prasarana olahraga yang tersebar di seluruh provinsi, dan yang saat ini sedang disiapkan adalah sarana dan prasarana olahraga di Jayapura yang dibangun untuk PON Papua 2021, yang terdiri dari 30 venue olahraga tersebar di 4 kabupaten/ kota di Papua.

Dengan ketersediaan sarana yang cukup dan tersebar di seluruh provinsi sebenarnya bisa dikatakan cukup untuk mendukung pembinaan olahraga di daerah, sebagai penyokong prestasi olahraga nasional. Ketersediaan sarana dan prasarana itu pun seharusnya mampu meningkatkan partisipasi masyarakat untuk berolahraga. Belum lagi dengan potensi penyelenggaraan event-event olahraga yang tentunya menguntungkan. Namun sayangnya prasarana dan sarana olahraga yang tersedia saat ini banyak yang tidak optimal digunakan dan tidak terawat bahkan rusak. Yang menjadi persoalan utama dalam pengelolaan sarana dan prasarana olahraga di Indonesia, adalah: (1) pengelolaan yang tidak fleksibel, (2) pemanfaatan yang tidak optimal, (3) akses yang terbatas, (4) fasilitas pendukung yang kurang memadai, dan anggaran pengelolaan yang minim (Harsono, 2020, hal. 1-15). Kemudian secara sederhana Tabel 1 menggambarkan kondisi nyata secara keseluruhan sarana dan prasarana olahraga di lokasi studi kasus.

Dari aspek keilmuan, di mana sarana dan prasarana olahraga merupakan salah satu instrumen pembangunan manusia, maka sarana dan prasarana olahraga harus dianggap sebagai barang publik, sehingga pengelolaannya merupakan ranah manajemen publik. Sarana dan prasarana olahraga juga merupakan suatu bentuk pelayanan publik. Dalam paradigma New Public Management, sarana dan prasarana olahraga merupakan suatu produk layanan dan masyarakat serta atlet adalah pelanggan yang harus mendapatkan kepuasan layanan sesuai standar. Kemudian bergeser ke paradigma New Public Service, sarana dan prasarana olahraga merupakan suatu layanan di mana masyarakat sebagai warga negara memiliki hak 
Tabel 1. Kondisi Sarana dan Prasarana Olahraga dan Lembaga Pengelolanya

\begin{tabular}{|c|c|c|}
\hline Venue & Pengelola & Kondisi Saat Ini \\
\hline Venue Aquatic & Dispora Riau (UPT) & $\begin{array}{l}\text { - Kondisi air sangat kotor } \\
\text { - Anggaran pengelolaan minim }\end{array}$ \\
\hline Jakabaring Tenis Court & $\begin{array}{l}\text { BUMD PT. Jakabaring } \\
\text { Sport City }\end{array}$ & $\begin{array}{l}\text { - Biaya operasional lebih tinggi } \\
\text { dibandingkan dengan } \\
\text { pendapatan BUMD } \\
\text { - Prasarana pendukung kurang } \\
\text { terawat }\end{array}$ \\
\hline $\begin{array}{l}\text { - Sarana Olahraga Arcamanik } \\
\text { - Stadion Gelora Bandung Lautan } \\
\text { Api }\end{array}$ & $\begin{array}{l}\text { Dispora Jawa Barat } \\
\text { (UPT) }\end{array}$ & $\begin{array}{l}\text { - Anggaran pemeliharaan belum } \\
\text { mencukupi } \\
\text { - Prasarana pendukung rusak } \\
\text { (Tribun, pintu masuk, ruang ganti, } \\
\text { dll) }\end{array}$ \\
\hline $\begin{array}{l}\text { - Stadion Utama Palaran } \\
\text { - Hotel Atlet Sempaja } \\
\text { - Gelanggang Olahraga Sempaja } \\
\text { - Stadion Atletik Sempaja }\end{array}$ & $\begin{array}{l}\text { Dispora Kalimantan } \\
\text { Timur (UPT) }\end{array}$ & $\begin{array}{l}\text { - Anggaran hanya digunakan untuk } \\
\text { kebutuhan utilitas rutin (air dan } \\
\text { listrik) } \\
\text { - Venue mengalami kerusakan } \\
\text { berat sehina tidak layak pakai }\end{array}$ \\
\hline
\end{tabular}

untuk turut menentukan keputusan mengenai standar layanan dan penggunaan sumber-sumber publik untuk pengadaannya. Dalam konteks kebijakan nasional, Pemerintah telah mengaturnya dalam Undang-Undang Nomor 3 Tahun 2005 tentang Sistem Keolahragaan Nasional. Berdasarkan Undang-Undang tersebut, Pemerintah berkewajiban untuk menyediakan prasarana olahraga sesuai standar dan kebutuhan. Kemudian dalam aturan tersebut. Lebih jauh lagi dalam Peraturan Pemerintah Nomor 16 Tahun 2007 tentang Penyelenggaraan Keolahragaan, diatur tentang kewajiban Pemerintah, Pemerintah Provinsi, dan Pemerintah Kabupaten/Kota dalam meningkatkan kualitas dan kuantitas prasarana dan sarana olahraga, baik untuk kepentingan prestasi olahraga maupun untuk kepentingan olahraga masyarakat dan rekreasi. Bahkan di dalamnya diatur pelibatan masyarakat dalam pengadaan prasarana dan sarana olahraga dalam konteks pembinaan olahraga masyarakat.

Beberapa penelitian yang fokus pada sarana prasarana olahraga untuk kepentingan industri olahraga, di antaranya menyimpulkan bahwa situasi pengelolaan sarana dan prasarana olahraga di Indonesia tidak sempurna, penyebabnya adalah benturan kepentingan yang membuat tidak kondusifnya upaya pemanfaatan sehingga mengabaikan fungsi dasar dari sarana dan prasarana olahraga (Rismayanthi, 2007). Dalam kaitannya dengan fasilitas pendidikan di mana sarana dan prasarana olahraga juga merupakan bagian dari fasilitas pendidikan, terdapat beberapa hal yang harus diperhatikan, yaitu: perencanaan, pengadaan, inventarisasi, penyimpanan, penataan, penggunaan, pemeliharaan, dan penghapusan (Prihatin, 2011, hal. 1-12). Kemudian poin-poin tersebut dijadikan kerangka kerja dalam penelitian pengelolaan sarana dan prasarana olahraga di sekolah (Riyes, 2015, hal. 10-17). Di samping itu banyak penelitian terkait sarana dan prasarana olahraga yang sifatnya melakukan evaluasi kelayakan dalam skala kecil, misalnya kelayakan sarana dan prasarana olahraga di kampus (Patrian et al., 2018, hal. 1-15), dan sport center di
Lamongan yang dapat berkembang pesat karena mempertimbangkan kebutuhan pasar (Prastio, 2014). Penelitian sarana dan prasarana olahraga nasional masih bersifat mikro terkait sarana prasarana olahraga di sekolah, ataupun ukuran-ukuran yang sangat teknis, seperti metodemetode teknis perawatan sarana dan prasarana olahraga. Dalam konteks yang lebih makro, fasilitas olahraga juga memiliki keterkaitan yang sangat erat terhadap Sport Development Index (SDI). Mengingat SDI memiliki 4 dimensi, yaitu: ruang terbuka, tenaga keolahragaan, partisipasi masyarakat, dan kebugaran jasmani, di mana keempatnya merupakan satu kesatuan yang tidak dapat dipisahkan untuk mengukur keberhasilan pembangunan olahraga (Mutohir \& Maksum, 2007). Di dalamnya dikembangkan pengukuran yang detail dengan perhitungan indeks terhadap masingmasing dimensi tersebut, termasuk indeks ketersediaan ruang terbuka sebagai fasilitas olahraga.

Oleh karena itu, perlu mengembangkan kerangka kerja untuk melihat pengaruh pembiayaan publik terhadap pemanfaatan fasilitas olahraga dari perspektif administrasi publik, yaitu new public management, tata kelola, dan pembiayaan (Iversen \& Cuskelly, 2015, hal. 529-541). Di sisi lain, sarana dan prasarana olahraga harus mengikuti kebutuhan pelanggan di mana pengelolaannya juga terkait dengan pertentangan antara fungsi sosial fasilitas olahraga dan efisiensi rasional untuk kinerja layanan yang lebih baik (Kruszyńska et al., 2018, hal. 157-167). Artinya persoalan pengelolaan sarana dan prasarana olahraga harus dilihat dari perspektif manajemen pelayanan publik, sehingga dapat ditemukan akar persoalan sesungguhnya agar dapat memberikan rekomendasi perbaikan yang efektif.

Di Amerika Utara, pengembangan sarana dan prasarana olahraga fokus pada rencana pengembangan kota dan diharapkan penelitiannya berkembang ke arah teori tata kelola yang lebih baru ketimbang teori keuangan neoklasik. Studi 
yang perlu dikembangkan ke depan terkait pengelolaan sarana dan prasarana olahraga adalah pada analisis yang lebih luas mencakup teori studi perencanaan kota, kewirausahaan, kinerja dan kapitalisme perkotaan (Jakar, 2020, hal. 1). Di samping itu juga terdapat perbedaan persepsi layanan venue pelanggan terhadap pelayanan yang diberikan venue olahraga dalam kegiatan-kegiatan sosial nonolahraga, sehingga dapat menjadi pertimbangan pemanfaatan venue olahraga untuk keperluan lain selain olahraga (Lee et al., 2015, hal. 164-180). Sama halnya dengan di Indonesia, di Amerika pembangunan fasilitas olahraga sering kali menjadi janji politik, di mana pada pelaksanaannya menjadi perdebatan karena menggunakan sumber daya publik yang cukup besar (Hutchinson et al., 2018, hal. 263-278).

Di China proporsi struktur bisnis stadion olahraga skala besar dianggap tidak masuk akal, dan manajemen berada dalam perkembangan yang terpolarisasi, dengan tingkat pemanfaatan yang rendah. Secara umum pengelolaan stadion di China dipengaruhi oleh lingkungan mikro-eksternal dan kondisi internal dari lokasi tersebut (Chen, 2019, hal. 76-79). Sedangkan untuk sarana dan prasarana olahraga kampuskampus di China, bergeser orientasinya seiring reformasi dan keterbukaan di China ke orientasi pasar. Sehingga sarana dan prasarana kampus juga menjadi terbuka untuk umum, dan masih menjadi isu penting bagi para pengelola kampus terkait efisiensi pengelolaannya (Sun, 2015, hal. 114-117).

Di Eropa saat ini sedang berkembang model pengelolaan sarana dan prasarana yang mengedepankan hospitality yang lebih komprehensif dan perluasan pemanfaatan Internet of Thing (IoT). Secara umum terdapat 3 tren utama yang mendorong inovasi pengelolaan sarana dan prasarana di Eropa untuk memasuki pasar bisnis, yaitu: inklusivitas, pencatatan pengalaman (costumer big data), dan peningkatan bisnis marketplace (Fast Forward Advisors, 2018). Di London, sebagai kota olahraga terbaik di dunia, pembangunan stadion baru selalu menjadi bagian rencana pengembangan wisata secara komprehensif terutama terkait dengan aksesibilitas dan transportasi (Humphreys, 2019, hal. 91-116).

Dari sekian banyak penelitian terkait dengan pengelolaan sarana dan prasarana olahraga, kerangka kerja analisis yang paling lengkap adalah yang disampaikan Schwarz et al. (2019) dalam bukunya yang berjudul "Sport Facility Operations Management" yang secara rinci dan komprehensif memberikan acuan pengelolaan sarana dan prasarana mulai dari awal hingga pengembangannya. Berikut adalah kerangka kerja yang disampaikan oleh Schwarz et al. tersebut, yaitu: (1) Isu Pramanajemen dan Praoperasional, (2) Manajemen Pelaksanaan dan Strategi Operasional, (3) Permasalahan, dan (4) Efektivitas Manajemen dan Operasional (Schwarz et al., 2019, hal. 9).

Berdasarkan pemetaan literatur penelitian sebelumnya dan permasalahan nyata di lapangan, maka kajian ini ditujukan untuk menjawab bagaimana pengelolaan sarana dan prasarana olahraga di Indonesia dengan studi kasus pada lima lokasi, yaitu Sumatera Selatan, Kalimantan Timur, Riau, Jawa Barat, dan DKI Jakarta? Dari situ diharapkan dapat digali persoalan sesungguhnya dari tidak terkelolanya dengan baik sarana dan prasarana olahraga di beberapa daerah. Peneliti akan melihat fenomena persoalan pengelolaan sarana dan prasarana olahraga dengan kerangka kerja yang dikembangkan oleh Schwarz et al. (2009) tentang manajemen operasional sarana dan prasarana olahraga. Mengingat kerangka kerja tersebut dibangun dengan pengalaman pengelolaan sarana dan prasarana olahraga di 5 benua maka kerangka kerja ini dianggap dapat memberikan perspektif global (Schwarz et al., 2019), sehingga dapat juga digunakan untuk meneropong persoalan sarana prasarana olahraga di Indonesia.

Untuk melengkapi kerangka kerja Schwarz et al. (2019), penulis akan mengombinasikannya dengan dokumen yang bersifat praktis, yaitu prinsip-prinsip pembangunan sarana dan prasarana olahraga di Australia pada 2018, dan kerangka kerja pembangunan sarana dan prasarana olahraga yang dikembangkan di New Zealand pada 2017. Kerangka kerja yang bersifat praktis tersebut dapat memperkuat penggunaan landasan teori yang sudah ada dalam kerangka kerja Schwarz dari aspek benchmarking secara praktis, sehingga dapat mengupas persoalan secara seimbang dari aspek teoritis dan dari aspek praktisnya. Meskipun tidak dapat dibandingkan secara langsung antara Indonesia, Australia, dan Selandia Baru, namun membandingkan dengan kedua negara yang sudah lebih maju tersebut dapat merupakan upaya visioner yang memandang jauh ke depan untuk masa depan olahraga Indonesia yang maju. Di samping itu penelitian ini tidak membandingkan kondisi nyata antara negara tersebut, hanya menggunakan prinsip-prinsip yang dikembangkan di kedua negara tersebut sebagai salah satu referensi praktis untuk melengkapi kerangka kerja analisis yang sudah ada. Dari aspek kompleksitas, kerangka kerja praktis tersebut tidak menyentuh perihal regulasi dan keterlibatan, namun hanya benar-benar berbicara tentang bagaimana sarana dan prasarana olahraga dibangun.

Kemudian faktor tingkat pembudayaan olahraga masyarakatnya juga penting untuk dilihat bagaimana minat masyarakat berolahraga sebagai pasar atau pelanggan dari sarana dan prasarana yang disediakan. Capaian prestasi juga perlu dilihat untuk mengetahui dari aspek dampak pemanfaatan yang optimal, sehingga terlihat manfaat dari keberadaan sarana dan prasarana itu sendiri terhadap peningkatan prestasi olahraga. Secara sederhana, kerangka pikir penelitian dapat dilihat pada Gambar 1.

Di samping itu, mengingat perbedaan kondisi di setiap wilayah, maka dilakukan perbandingan dari setiap kompleks olahraga dengan indikator yang telah ditetapkan, sehingga akan terlihat keunikan persoalan dari setiap kompleks olahraga dalam studi kasus ini.

\section{Metode}

Kajian ini menggunakan pendekatan kualitatif untuk dapat memahami fenomena sosial yang terjadi secara komprehensif 

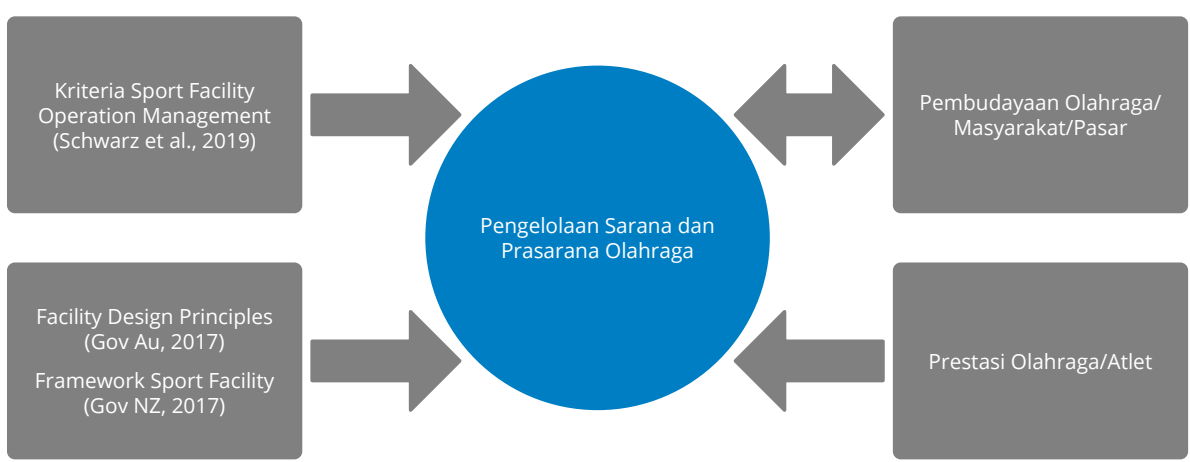

Gambar 1. Kerangka Pikir Penelitian

(Wilson \& Creswell, 1996, hal. 252-255), di samping itu penelitian ini pada dasarnya mencoba menjawab pertanyaan bagaimana pengelolaan sarana dan prasarana olahraga, dan mencoba menjawab mengapa hal tersebut terjadi. Dengan pendekatan kualitatif diharapkan dapat ditemukan persoalanpersoalan spesifik dan mendalam dari sarana dan prasarana di lapangan. Metode yang digunakan adalah metode deskriptif untuk dapat menjelaskan fenomena yang terjadi dalam konteks kerangka teori yang digunakan, mengingat penelitian ini akan menjelaskan secara deskriptif dalam menjawab pertanyaan penelitian. Teknik analisisnya adalah ilustratif karena menjadikan indikator-indikator dalam kerangka teori yang digunakan sebagai wadah kosong yang kemudian diisi dengan data-data yang relevan di lapangan (Neuman, 2014, hal. 489). Data - datanya adalah data sekunder yang merupakan laporan hasil monitoring dan evaluasi yang pada dasarnya merupakan hasil wawancara para pelaksana monitoring dan evaluasi dengan pengelola sarana dan prasaran di lapangan, dan dokumen - dokumen terkait yang diperlukan berupa laporan pelaksanaan tugas, dokumentasi lapangan, dan lain sebagainya. Sebagaimana Neuman, data-data tersebut kemudian dipilah untuk diklasifikasi berdasarkan indikatorindikator dalam kerangka kerja, untuk kemudian dianalisis dengan membandingkan prinsip-prinsip dalam kerangka kerja analisis. Untuk memudahkan pemahamannya, maka data disajikan dalam tabel yang berisi narasi dari masing-masing kondisi sarana dan prasarana terhadap prinsip-prinsip pengelolaan dalam kerangka kerja analisis yang digunakan.

Dari aspek obyek kajian, kajian ini merupakan kajian studi kasus terhadap beberapa lokasi yang dianggap memiliki keterwakilan perbedaan dan beberapa persamaan di antaranya disiapkan untuk penyelenggaraan multievent olahraga, yaitu: kompleks olahraga Gelora Bung Karno Jakarta, kompleks olahraga Jakabaring Sumsel, Stadion Utama Riau, kompleks Olahraga Kalimantan Timur (Stadion Utama Palaran dan Stadion Madya Sempaja). Studi kasus dianggap mampu menyelidiki suatu peristiwa, situasi, atau kondisi sosial tertentu dan untuk memberikan pemahaman dalam proses terjadinya suatu fenomena sosial (Hodgetts \& Stolte, 2012, hal. 379-389). Pengambilan data dilakukan antara tahun 2017 hingga tahun 2020 ke lokasi-lokasi tersebut di atas, baik ke lokasi kantor pengelola, dan survei langsung ke lokasi venue.
Survei dilakukan dengan melihat langsung kondisi sarana dan prasarana olahraga secara fisik dan bagaimana masyarakat memanfaatkan sarana dan prasarana olahraga tersebut di harihari tertentu.

Sedangkan terkait kerangka analisis yang digunakan adalah kerangka kerja analisis yang dianggap paling lengkap yaitu yang disampaikan Schwarz et al. (2019), dalam bukunya yang berjudul "Sport Facility Operations Management" yang secara rinci dan komprehensif memberikan acuan pengelolaan sarana dan prasarana mulai dari awal hingga pengembangannya. Berikut adalah kerangka kerja yang disampaikan oleh Schwarz tersebut, yaitu: (1) Isu Pramanajemen dan Praoperasional, (2) Manajemen Pelaksanaan dan Strategi Operasional, (3) Permasalahan, dan (4) Efektivitas Manajemen dan Operasional (Schwarz et al., 2019). Kerangka kerja tersebut juga dibangun dengan pengalaman pengelolaan sarana dan prasarana olahraga di 5 benua, maka kerangka kerja ini dianggap dapat memberikan perspektif global (Schwarz et al., 2019), sehingga dapat juga digunakan untuk meneropong persoalan sarana prasarana olahraga di Indonesia.

Untuk melengkapi kerangka kerja Schwarz, juga akan digunakan kerangka analisis praktis, yang digunakan di Australia dan Selandia Baru, yaitu prinsip-prinsip pembangunan sarana dan prasarana olahraga di Australia tahun 2018 yang terdiri dari practical and affordable for the long term, fit for purpose, multi and shared use, future proofed, flexible and functional space, universal design, bealth and safety, environmental sustainability, location-access and public realm (Government of South Australia, 2018). Dan kerangka kerja pembangunan sarana dan prasarana olahraga yang diberlakukan Pemerintah New Zealand, untuk memperkuat analisis, yang terdiri dari 6 kriteria, yaitu: accessibility, sustainability, future proofing, meeting and identified needed, partnering and collaboration, dan integration (Sport New Zealand, 2017). Enam kriteria tersebut pada dasarnya hampir sama dengan prinsip-prinsip yang diterapkan di Australia, kecuali kriteria partnering dan collaboration, yang terkait dengan lembaga pengelolaan yang melibatkan pihak di luar pemerintah, dan integration yang terkait dengan keterpaduan dengan pembangunan sarana dan prasarana di bidang lainnya. 


\section{Hasil dan Pembahasan}

\subsection{Analisis Kerangka Kerja Schwarz et al. (2019)}

Sarana dan prasarana olahraga merupakan hal penting dalam meningkatkan prestasi olahraga sekaligus membangun budaya olahraga di masyarakat. Lebih jauh lagi sarana dan prasarana olahraga merupakan salah satu modal industri olahraga yang paling vital dan memiliki potensi ekonomi yang begitu besar. Dalam skala makro, sarana dan prasarana olahraga merupakan salah satu instrumen penting pembangunan manusia. Untuk itu selanjutnya pada bagian ini, kerangka kerja manajemen operasional sarana dan prasarana olahraga Schwarz et al. (2019) sebagai landasan teoritis, akan dioperasionalkan dengan cara menyandingkannya terhadap kondisi nyata tentang sarana dan prasarana olahraga di Indonesia (Tabel 2).

Berdasarkan Tabel 2 terlihat bahwa kompleks olahraga Gelora Bung Karno yang paling banyak memenuhi kriteria. Dari aspek kelembagaan, lembaga pengelola dalam bentuk Pusat Pengelolaan Komplek Gelora Bung Karno (PPK GBK), yang merupakan BLU di bawah Sekretariat Negara memiliki fleksibilitas dalam pengelolaan keuangannya. Biaya pengelolaan kompleks olahraga GBK bersumber dari para pelanggan yang memanfaatkan kompleks olahraga GBK, di mana sudah ditetapkan tarif untuk masing-masing venue di dalamnya oleh PPK GBK. Untuk melihat okupansinya, dari daftar pemesanan lapangan sepakbola $\mathrm{ABC}$ terlihat daftar antrean yang cukup panjang. Dari situ bisa diartikan bahwa tingkat pemanfaatan kompleks olahraga GBK oleh masyarakat cukup baik, khususnya untuk lapangan sepakbola. Tingginya pemanfaatan, membuat perawatan kompleks olahraga GBK berjalan dengan baik dan sesuai standar. Dari tingginya pemanfaatan juga dapat terlihat bahwa terdapat fungsi marketing yang berjalan dengan baik, dengan mengedepankan internet of thing (IoT). Dari aspek rehabilitasi, meskipun untuk penyelenggaraan Asian Games 1962, kompleks olahraga GBK sudah melakukan renovasi dan modernisasi yang signifikan di semua venue, dan relevan terhadap penggunaan saat ini, dengan berbagai standar penggunaan yang rumit, di antaranya keamanan, kesehatan, ramah anak, dan ramah perempuan.

Tabel 2. Operasionalisasi Konsep Manajemen Operasional Sarana dan Prasarana Olahraga

\begin{tabular}{|c|c|c|c|c|c|}
\hline $\begin{array}{l}\text { Kriteria Pengelolaan } \\
\text { Schwarz et al. (2019) }\end{array}$ & GBK & Jakabaring & Riau & Kaltim & Jabar \\
\hline \multicolumn{6}{|c|}{ Pre-management and Pre-operational Issues } \\
\hline Ownership structures & Pemerintah & Pemerintah & Pemerintah & Pemerintah & Pemerintah \\
\hline Financing sport facilities & Pelanggan & Pelanggan & APBD & APBD & APBD \\
\hline $\begin{array}{l}\text { Planning, design, and } \\
\text { construction processes }\end{array}$ & $\begin{array}{l}\text { - Untuk AG 1962, } 2018 \\
\text { - Sesuai aturan RTH } \\
\text { - Di tengah kota } \\
\text { - Rehab modernisasi }\end{array}$ & $\begin{array}{l}\text { - Untuk PON } 2004 \text { \& AG } \\
2018 \\
\text { - Di pinggir kota (buka } \\
\text { daerah baru) } \\
\text { - Desain modern }\end{array}$ & $\begin{array}{l}\text { - Di pinggir kota (buka } \\
\text { daerah baru) } \\
\text { - Desain modern }\end{array}$ & $\begin{array}{l}\text { Di pinggir kota (buka } \\
\text { daerah baru) } \\
\text { - Desain modern }\end{array}$ & $\begin{array}{l}\text { - Di pinggir kota (buka } \\
\text { daerah baru) } \\
\text { - Desain modern }\end{array}$ \\
\hline \multicolumn{6}{|c|}{ Implementation of Management and Operational Strategies } \\
\hline $\begin{array}{l}\text { Organizational } \\
\text { management }\end{array}$ & BLU & BUMD & UPTD & UPTD & UPTD \\
\hline $\begin{array}{l}\text { Human resource } \\
\text { management }\end{array}$ & ASN dan Non-ASN & Pegawai swasta & ASN & ASN & ASN \\
\hline Financial management & $\begin{array}{l}\text { Layanan umum tidak } \\
\text { mencari keuntungan }\end{array}$ & $\begin{array}{l}\text { Profit oriented. Tidak } \\
\text { dapat memenuhi } \\
\text { kebutuhan biaya } \\
\text { perawatan }\end{array}$ & $\begin{array}{l}\text { Keuangan negara. } \\
\text { Alokasi anggaran minim }\end{array}$ & $\begin{array}{l}\text { Keuangan negara. } \\
\text { Alokasi anggaran minim }\end{array}$ & $\begin{array}{l}\text { Keuangan negara. } \\
\text { Alokasi anggaran minim }\end{array}$ \\
\hline Operations management & Sesuai standar cabor & $\begin{array}{l}\text { Jauh di bawah standar } \\
\text { pemeliharaan }\end{array}$ & $\begin{array}{l}\text { Jauh di bawah standar } \\
\text { pemeliharaan }\end{array}$ & $\begin{array}{l}\text { Jauh di bawah standar } \\
\text { pemeliharaan }\end{array}$ & $\begin{array}{l}\text { Jauh di bawah standar } \\
\text { pemeliharaan }\end{array}$ \\
\hline $\begin{array}{l}\text { Legal concerns for owners } \\
\text { and managers }\end{array}$ & $\begin{array}{l}\text { Kewenangan } \\
\text { pengelolaan terbatas }\end{array}$ & $\begin{array}{l}\text { Kewenangan penuh } \\
\text { diberikan kepada } \\
\text { BUMD }\end{array}$ & $\begin{array}{l}\text { Kewenangan } \\
\text { pemerintah }\end{array}$ & $\begin{array}{l}\text { Kewenangan } \\
\text { pemerintah }\end{array}$ & $\begin{array}{l}\text { Kewenangan } \\
\text { pemerintah }\end{array}$ \\
\hline \multicolumn{6}{|c|}{ Ancillary Issues in Management and Operations } \\
\hline $\begin{array}{l}\text { Facility marketing } \\
\text { management }\end{array}$ & Internet of Things & Manual/tradisional & Tidak ada & Tidak ada & Tidak ada \\
\hline $\begin{array}{l}\text { Event planning in facility } \\
\text { management }\end{array}$ & $\begin{array}{l}\text { Menerima banyak } \\
\text { permintaan }\end{array}$ & Minim permintaan & & & \\
\hline $\begin{array}{l}\text { Risk assessment in facility } \\
\text { management }\end{array}$ & Standar & Standar & Standar & Standar & Standar \\
\hline $\begin{array}{l}\text { Security planning for facility } \\
\text { management }\end{array}$ & Standar & Standar & Standar & Standar & Standar \\
\hline
\end{tabular}


Sedangkan untuk kompleks olahraga Jakabaring, pengelolaannya diserahkan kepada BUMD milik Provinsi Sumatera Selatan, sehingga lembaga pengelola kompleks olahraga Jakabaring bersifat profit oriented. Dengan sifat tersebut artinya, pengelola kompleks olahraga Jakabaring harus bisa mendapatkan penerimaan yang berasal dari pemanfaatan kompleks olahraga Jakabaring oleh masyarakat, yang digunakan untuk biaya perawatan. Namun yang terjadi di lapangan adalah tidak sebandingnya antara biaya perawatan dengan okupansi pemanfaatan kompleks olahraga Jakabaring oleh masyarakat. Sehingga banyak venue yang tidak terawat. Dari sejarah pembangunannya, kompleks olahraga Jakabaring dibangun pertama kali untuk keperluan PON 2004, dan kemudian direnovasi dan dilengkapi untuk digunakan pada Sea Games 2011, serta yang terakhir digunakan pada Asian Games 2018. Dari aspek lokasi, memang cukup jauh dari pusat pemukiman dan pusat pemerintahan, namun pada tahun 2018 kompleks olahraga Jakabaring sudah dihubungkan dengan LRT, dari Bandara, pusat kota, hingga Jakabaring.

Kemudian untuk tiga lokasi lainnya, semuanya masih dikelola oleh Pemerintah Provinsi. Terkait dengan pembiayaan, berdasarkan penuturan para pengelola atau Dinas yang mengurusi keolahragaan, pembiayaan APBD sangat minim sehingga tidak dapat menutupi kebutuhan biaya perawatan yang sesuai standar. Tentang pemanfaatannya, mengingat lembaga pengelolanya adalah UPT maka akan sulit mengatur penerimaan yang dapat dimanfaatkan langsung untuk perawatan, mengingat UPT tunduk pada aturan pengelolaan APBD, sehingga tidak fleksibel dan akan menghambat pengelolaan karena panjangnya prosedur. Di samping itu, semua perawatan tidak sesuai standar venue untuk dapat mempertandingkan kembali pertandingan bertaraf internasional sesuai standar PB Cabor, bahkan tidak terawat dan mengalami kerusakan.

Persoalan yang ada pada dasarnya tidak hanya terkait dengan lembaga pengelolanya, karena dilihat di Jakabaring dengan revolusi pengelola oleh BUMD pun gagal, faktor pasar sangat menentukan. Pengelolaan oleh UPTD pada dasarnya juga dimungkinkan ketika memang venue dibangun untuk pembinaan prestasi tanpa mengharapkan penerimaan untuk perawatan, namun daerah seperti tidak memiliki rencana jangka panjang pengelolaan sejak venue dibangun. Berdasarkan Tabel 2, wajar apabila kemudian hanya kompleks olahraga Gelora Bung Karno yang pengelolaannya berjalan dengan baik, karena memenuhi semua kriteria pengelolaan.

\subsection{Analisis Prinsip-Prinsip Pembangunan Sarana dan Prasarana yang Baik Berdasarkan Pengalaman Australia}

Selanjutnya adalah mengoperasionalkan prinsip-prinsip pembangunan sarana dan prasarana olahraga di Australia tahun 2018 yang terdiri dari practical and affordable for the

Tabel 3. Operasionalisasi Prinsip-Prinsip Pembangunan Sarana dan Prasarana Olahraga

\begin{tabular}{|c|c|c|c|c|c|}
\hline $\begin{array}{c}\text { Prinsip-Prinsip } \\
\text { Pembangunan } \\
\text { Sarana dan } \\
\text { Prasarana Olahraga } \\
\text { dan Rekreasi (Gov. } \\
\text { of South Aus., 2018) }\end{array}$ & GBK & Jakabaring & Riau & Kaltim & Jabar \\
\hline $\begin{array}{l}\text { Practical and affordable for } \\
\text { the long-term }\end{array}$ & Memenuhi & Tidak memenuhi & Tidak memenuhi & Tidak memenuhi & Tidak memenuhi \\
\hline Fit for purpose & $\begin{array}{l}\text { - Sesuai kebutuhan dan } \\
\text { standar } \\
\text { - Multipurpose }\end{array}$ & $\begin{array}{l}\text { - Sesuai standar } \\
\text { - Multipurpose }\end{array}$ & Sesuai standar & Sesuai standar & $\begin{array}{l}\text { - Sesuai standar } \\
\text { - Multipurpose }\end{array}$ \\
\hline Multi and shared use & Memenuhi & Memenuhi & Tidak memenuhi & Tidak memenuhi & Memenuhi \\
\hline Future proofed & $\begin{array}{l}\text { Tidak memungkinkan } \\
\text { perluasan }\end{array}$ & $\begin{array}{l}\text { Memungkinkan } \\
\text { perluasan }\end{array}$ & $\begin{array}{l}\text { Memungkinkan } \\
\text { perluasan }\end{array}$ & $\begin{array}{l}\text { Memungkinkan } \\
\text { perluasan }\end{array}$ & $\begin{array}{l}\text { Memungkinkan } \\
\text { perluasan }\end{array}$ \\
\hline $\begin{array}{l}\text { Flexible and functional } \\
\text { space }\end{array}$ & $\begin{array}{l}\text { - Tidak fleksibel } \\
\text { - Fasilitas pendukung } \\
\text { lengkap }\end{array}$ & $\begin{array}{l}\text { - Tidak fleksibel } \\
\text { - Fasilitas pendukung } \\
\text { lengkap }\end{array}$ & Tidak fleksibel & Tidak fleksibel & Tidak fleksibel \\
\hline Universal design & Universal & Universal & Universal & Universal & Universal \\
\hline Health and safety & $\begin{array}{l}\text { - Ramah difabel, } \\
\text { perempuan, dan anak } \\
\text { - Aman }\end{array}$ & - & - & - & - \\
\hline Environmental stability & - & - & - & - & - \\
\hline $\begin{array}{l}\text { Location, access, and the } \\
\text { public realm }\end{array}$ & $\begin{array}{l}\text { - } 0 \text { km dari pusat kota } \\
\text { - Transportasi umum: } \\
\text { busway, MRT, dll. } \\
\text { - Sangat mudah }\end{array}$ & $\begin{array}{l}\text { - 4,6 km dari pusat kota } \\
\text { - Transportasi umum: } \\
\text { LRT, angkot } \\
\text { - Di pinggir kota }\end{array}$ & $\begin{array}{l}\text { - } 10,8 \text { km dari pusat } \\
\text { kota } \\
\text { - Transportasi umum: } \\
\text { angkot } \\
\text { - Di pinggir kota }\end{array}$ & $\begin{array}{l}\text { - } 18,6 \text { km dari pusat } \\
\text { kota } \\
\text { - Transportasi umum: } \\
\text { angkot } \\
\text { - Di pinggir kota }\end{array}$ & $\begin{array}{l}\text { - 7,2 km dari pusat kota } \\
\text { - Transportasi umum: } \\
\text { angkot } \\
\text { - Di pinggir kota }\end{array}$ \\
\hline
\end{tabular}

Sumber: Diolah peneliti berdasarkan Kerangka Kerja Pembangunan Sarana dan Prasarana di Australia 2017 dan data lapangan 
long term, fit for purpose, multi and shared use, future proofed, flexible and functional space, universal design, health and safety, environmental sustainability, location-access and public realm (Government of South Australia, 2018), dengan kondisi nyata pengelolaan sarana dan prasarana di 5 lokasi studi kasus (Tabel 3).

Berdasarkan perspektif prinsip-prinsip pembangunan sarana dan prasarana olahraga dan rekreasi yang dikembangkan Pemerintah Australia, dari lima lokasi studi kasus, hanya Gelora Bung Karno yang memenuhi kriteria. Di mana Gelora Bung Karno sudah dianggap memiliki rencana pengelolaan jangka panjang yang baik, pemanfaatan untuk berbagai macam kegiatan, dukungan fasilitas yang lengkap, mudah dicapai dengan aksesibilitas yang sangat baik, aman dan ramah difabel, perempuan dan anak. Namun stadion Gelora Bung Karno belum mengaplikasikan penggunaan energi terbarukan atau hemat penggunaan air untuk mendukung kelestarian lingkungan secara berkelanjutan.

Untuk kompleks olahraga lainnya, semuanya hampir tidak memenuhi kriteria pengelolaan berdasarkan prinsip-prinsip pengelolaan sarana dan prasarana olahraga dan rekreasi yang diberlakukan di Australia. Dari aspek lokasi, semuanya berada jauh dari pusat kota dan dengan akses transportasi umum yang tidak begitu baik, hanya disediakan transportasi umum berupa angkutan kota yang tidak nyaman dan saat ini sudah tidak diminati. Berbeda dengan di Palembang yang didukung oleh LRT, yang itu pun masih tidak diminati oleh masyarakat Palembang.

Lokasi yang jauh dari pusat kota atau keramaian tentunya menjadi nilai minus tersendiri untuk mendatangkan banyak masyarakat. Kalaupun berhasil mendatangkan masyarakat hanya pada satu waktu tertentu dalam seminggu, itu pun tidak dimanfaatkan dengan optimal oleh pengelola, dengan kegiatan kreatif ataupun dengan membuka promosi pemanfaatan venue oleh masyarakat umum secara masif. Dari sisi rencana jangka panjang pengelolaan, tampaknya semua sarana dan prasarana hanya dibangun untuk keperluan penyelenggaraan event, dan tidak ada rencana setelahnya. Gelora Bung Karno lebih beruntung karena berada di pusat kota Jakarta di mana sudah sulit ditemukan lokasi untuk berolahraga. Meskipun begitu, kecuali kompleks olahraga Gelora Bung Karno semuanya masih memungkinkan diadakan perluasan untuk antisipasi kemungkinan penggunaan yang lebih dimasa mendatang.

Sehingga yang menjadi poin penting dari operasionalisasi prinsip-prinsip ini sebagai kerangka analisis adalah yang terkait dengan rencana jangka panjang pemanfaatan yang harus sudah disiapkan sejak pertama kali sarana dan prasarana itu dibangun. Dan faktanya semuanya tidak menyiapkan hal tersebut secara detail, yang dapat terlihat bahwa Pemerintah Daerah hanya menyiapkan biaya pembangunan namun tidak mendukung biaya perawatan selanjutnya secara memadai dan berkelanjutan. Kemudian poin penting lainnya adalah yang terkait dengan aksesibilitas dan dukungan transportasi.

\subsection{Analisis Prinsip-Prinsip Pengelolaan Sarana dan Prarasana yang Baik Berdasarkan Pengalaman Selandia Baru}

Selanjutnya adalah operasionalisasi kerangka kerja pembangunan sarana dan prasarana yang diberlakukan di Selandia Baru, dengan menyandingkan 6 kriteria kerangka kerja pembangunan sarana dan prasarana di Selandia Baru dengan kondisi nyata di 5 lokasi studi kasus (Tabel 4).

Tabel 4. Operasionalisasi Kerangka Kerja Pembangunan Sarana dan Prasarana Olahraga

\begin{tabular}{|c|c|c|c|c|c|}
\hline $\begin{array}{c}\text { Kerangka Kerja } \\
\text { Pembangunan } \\
\text { Sarana dan } \\
\text { Prasarana Olahraga } \\
\text { \& Rekreasi (NZ Gov., } \\
\text { 2017) }\end{array}$ & GBK & Jakabaring & Riau & Kaltim & Jabar \\
\hline Accessibility & $\begin{array}{l}\text { - } 0 \text { km dari pusat kota } \\
\text { - Transportasi umum: } \\
\text { busway, MRT, dll. } \\
\text { - Sangat mudah }\end{array}$ & $\begin{array}{l}\text { - 4,6 km dari pusat kota } \\
\text { - Transportasi umum: } \\
\text { LRT, angkot } \\
\text { - Di pinggir kota }\end{array}$ & $\begin{array}{l}\text { - } 10,8 \text { km dari pusat } \\
\text { kota } \\
\text { - Transportasi umum: } \\
\text { angkot } \\
\text { - Di pinggir kota }\end{array}$ & $\begin{array}{l}\text { - } 18,6 \mathrm{~km} \text { dari pusat } \\
\text { kota } \\
\text { - Transportasi umum: } \\
\text { angkot } \\
\text { - Di pinggir kota }\end{array}$ & $\begin{array}{l}\text { - 7,2 km dari pusat kota } \\
\text { - Transportasi umum: } \\
\text { angkot } \\
\text { - Di pinggir kota }\end{array}$ \\
\hline Sustainability & - & $\cdot-$ & - & - & - \\
\hline Future proofing & Jangka panjang & Jangka panjang & - & - & Jangka panjang \\
\hline $\begin{array}{l}\text { Meeting and identified } \\
\text { needed }\end{array}$ & $\begin{array}{l}\text { - Sesuai kebutuhan dan } \\
\text { standar } \\
\text { - Multipurpose }\end{array}$ & $\begin{array}{l}\text { - Sesuai standar } \\
\text { - Multipurpose }\end{array}$ & Sesuai standar & Sesuai standar & $\begin{array}{l}\text { - Sesuai standar } \\
\text { - Multipurpose }\end{array}$ \\
\hline $\begin{array}{l}\text { Partnering and } \\
\text { collaboration }\end{array}$ & BLU & $\begin{array}{l}\text { - BUMD } \\
\text { - Sponsor }\end{array}$ & - & - & - \\
\hline Integration & - & Universal & Universal & Universal & Universal \\
\hline
\end{tabular}

Sumber: Diolah peneliti berdasarkan Kerangka Kerja Pembangunan Sarana dan Prasarana di Selandia Baru 2017 dan data lapangan 
Berdasarkan Tabel 4 dan fokus pada 2 kriteria terakhir yang tidak terdapat di prinsip-prinsip yang diterapkan di Australia, dapat diketahui bahwa semua kompleks olahraga yang menjadi lokasi studi kasus tidak memiliki tata kelola dengan model kemitraan dan kolaborasi. Komplek Olahraga Gelora Bung Karno dikelola dengan penyerahan wewenang secara terbatas melalui mekanisme Badan Layanan Umum, kemudian Komplek olahraga Jakabaring adalah penyerahan aset untuk dikelola oleh Badan Usaha Milik Daerah. Untuk kompleks olahraga lainnya masih dikelola secara murni oleh pemerintah daerah. Terkait dengan integrasi, semua venue tidak dibangun secara terencana dengan terintegrasi bersama fasilitas lainnya seperti fasilitas rekreasi, seni budaya, kesehatan, dan pusat perbelanjaan. Sehingga pengembangannya pun hanya dari aspek olahraga saja dan tidak ada alternatif daya tarik pasar atau masyarakat.

\subsection{Sarana dan Prasarana Olahraga dan Tingkat Partisipasi Olahraga Masyarakat}

Sebagaimana kerangka pikir penelitian ini, analisis selanjutnya adalah mengaitkan pengelolaan sarana dan prasarana dengan pembudayaan olahraga di masyarakat dan peningkatan prestasi olahraga untuk melengkapi analisis dari perspektif dampak. Tingkat partisipasi masyarakat dalam berolahraga ini dapat dijadikan pijakan awal untuk dapat mengukur tingkat pembudayaan olahraga yang lebih komprehensif. Dari perspektif Sport Development Index (SDI), ruang terbuka menjadi salah satu dimensi pengukuran SDI karena terkait dengan tempat masyarakat untuk berolahraga, baik dalam bentuk bangunan maupun lahan. Lebih jauh lagi terdapat pengukuran untuk melihat bagaimana rasio antara luas ruang terbuka dengan jumlah penduduk di atas usia 7 tahun (Mutohir \& Maksum, 2007). Terkait rasio tersebut berdasarkan argumentasi bahwa masyarakat dengan jumlah 3.500 orang dapat menggunakan ruang terbuka untuk berolahraga minimal seluas $12.000 \mathrm{~m} 2$, maka angka standar ruang terbuka adalah $3,5 \mathrm{~m} 2$ (Kristiyanto, 2012). Namun sayangnya data mengenai ruang terbuka dari masing-masing provinsi tersebut dalam konteks ruang terbuka untuk berolahraga belum bisa didapatkan. Saat ini data tingkat partisipasi masyarakat yang dirilis BPS masih menjadi satusatunya data yang digunakan untuk mengukur capaian pembangunan terkait pembudayaan olahraga. Data yang dikeluarkan BPS adalah persentase jumlah masyarakat usia 10 tahun ke atas yang melakukan aktivitas olahraga 1 minggu terakhir. Berdasarkan data tersebut yang dirilis BPS di tahun 2018 tentang tingkat partisipasi masyarakat yang berolahraga per provinsi, diketahui bahwa Jakarta memiliki tingkat partisipasi tertinggi 44,93\%, Jawa Barat 40,41\%, Kalimantan Timur 43,40\%, Sumatera Selatan 30,87\%, dan Riau 38,78\% (Badan Pusat Statistik-BPS, 2018). Dilihat dari angka tersebut, yang terjadi di 5 lokasi studi kasus dalam penelitian ini menunjukkan tidak ada keterkaitan antara tingkat partisipasi dengan ketersediaan venue atau kompleks olahraga. Untuk Jakarta dengan tingkat partisipasi tertinggi dan dikaitkan dengan ketersediaan sarana dan prasarananya dinilai wajar karena memang kuantitas dan kualitas sarana dan prasarana olahraga di Jakarta sangat mendukung dilihat dari kriteria pengelolaan yang telah disampaikan di atas.

Berdasarkan rilis data BPS tersebut, tingkat partisipasi olahraga di Jawa Barat masih berada di bawah Kalimantan Timur, kondisi ini menjadi pertanyaan, ketika tersedia sarana dan prasarana olahraga yang lebih baik namun tingkat partisipasi olahraganya, justru berada di bawah Kalimantan Timur yang apabila dilihat dari satu contoh sarana dan prasarana olahraganya banyak tidak memenuhi kriteria pengelolaan yang baik. Begitu juga dengan Sumatera Selatan dengan Jakabaringnya ternyata tidak mampu mengangkat tingkat partisipasi masyarakatnya dalam berolahraga, yang bahkan berada di bawah Riau. Dari aspek lain dapat dilihat mengapa tingkat pemanfaatan Jakabaring sangat rendah meskipun saat ini sudah dikelola oleh Badan Usaha Milik Daerah secara profesional, hal tersebut disebabkan tingkat partisipasi masyarakat dalam berolahraga di Sumatera Selatan memang rendah. Sehingga hal ini mentriangulasi hasil analis berdasarkan kriteria-kriteria pengelolaan sarana dan prasarana di atas yang terkait dengan rencana pemanfaatan jangka panjang dan identifikasi kebutuhannya.

Untuk Kalimantan Timur di mana tingkat partisipasi olahraga masyarakatnya relatif tinggi kemudian dihadapkan pada kondisi pengelolaan sarana dan prasarana yang tidak sesuai kriteria, hal ini dapat bermakna bahwa Kalimantan Timur hanya perlu meningkatkan aspek pengelolaan sarana dan prasarana olahraganya. Dengan tingkat partisipasi olahraga yang hampir sama dengan Jakarta, maka bukan tidak mungkin kompleks olahraga Sempaja dan Palaran dapat dimanfaatkan secara optimal oleh masyarakat Kalimantan Timur sebagaimana kompleks olahraga Gelora Bung Karno. Begitu juga dengan Riau yang memiliki tingkat partisipasi olahraga yang relatif tinggi dibandingkan seluruh provinsi, dibutuhkan pengelolaan yang lebih profesional agar tingkat pemanfaatannya dapat optimal.

\subsection{Sarana dan Prasarana Olahraga dan Prestasi Olahraga}

Setelah melihat kaitan antara sarana dan prasarana olahraga dengan tingkat partisipasi masyarakat dalam berolahraga, selanjutnya akan dilihat kaitan sarana dan prasarana di 5 lokasi studi kasus tersebut terhadap capaian prestasi olahraga 5 provinsi tersebut dalam penyelenggaraan Pekan Olahraga Nasional. Pekan Olahraga Nasional yang dilaksanakan 4 tahun sekali bisa dijadikan indikator pembinaan prestasi olahraga di provinsi. Dalam pembinaannya tentunya dibutuhkan ketersediaan sarana dan prasarana yang baik. Bahkan ketersediaan sarana dan prasarana merupakan salah satu faktor utama untuk dapat berprestasi. Untuk itu akan dilihat bagaimana capaian prestasi 5 provinsi tersebut dalam PON minimal di 10 penyelenggaraan PON terakhir.

Di tahun 2004 di mana Sumatera Selatan menjadi tuan rumah dan pertama kalinya Jakabaring digunakan, Sumatera Selatan duduk pada peringkat 4, kemudian Jakarta menjadi 
juara umum, Jawa Barat peringkat 3, Kalimantan Timur peringkat 9, dan Riau peringkat 11. Pada PON tahun 2008 di Kalimantan Timur, Jakarta duduk pada peringkat 2, Kalimantan Timur peringkat 3, Jawa Barat peringkat 4, Riau peringkat 10, dan Sumatera Selatan peringkat 14. Kemudian pada PON 2012 di Riau, Jakarta menjadi juara umum, Jawa Barat pada peringkat 2, Kalimantan Timur pada peringkat 5, Riau pada peringkat 6, dan Sumatera Selatan pada peringkat 13. Pada PON 2016 di Jawa Barat, Jawa Barat menjadi juara umum, Jakarta peringkat 3, Kalimantan Timur peringkat 5, Riau peringkat 7, dan Sumatera Selatan peringkat 18.

Dari capaian prestasi 5 provinsi tersebut dalam penyelenggaraan PON, capaian Jakarta dan Jawa Barat dirasa wajar terkait dengan ketersediaan sarana dan prasarana yang baik. Di mana Jakarta dan Jawa Barat selalu dalam posisi 3 besar bahkan juara umum. Sedangkan untuk Kalimantan Timur dan Riau dengan kondisi sarana dan prasarana yang banyak tidak memenuhi kriteria pengelolaan prasarana dan sarana olahraga di atas justru menempati peringkat yang baik dalam penyelenggaraan PON. Artinya meskipun dengan sarana dan prasarana seadanya namun dimanfaatkan dengan optimal untuk pembinaan prestasi olahraganya. Berbeda dengan Sumatera Selatan yang hanya dapat berprestasi masuk peringkat 5 besar pada saat menjadi tuan rumah. Namun setelahnya Sumatera Selatan sulit untuk masuk dalam peringkat 10 besar. Dengan adanya kompleks olahraga sekelas Jakabaring yang sesuai standar internasional dan sangat lengkap maka seharusnya Sumatera Selatan dapat mencapai prestasi yang baik, dibandingkan provinsi lainnya. Dari sini dapat dilihat bahwa Jakabaring tidak dimanfaatkan secara optimal untuk peningkatan prestasi olahraga.

\section{Kesimpulan}

Berdasarkan temuan penelitian dalam menjawab pertanyaan yang terkait dengan bagaimana pengelolaan sarana dan prasarana olahraga di Indonesia, dapat disimpulkan bahwa pada aspek perencanaan yang terkait dengan pemanfaatan jangka panjang ke depan baik untuk keperluan olahraga masyarakat dan rekreasi maupun untuk keperluan peningkatan prestasi, tidak menjadi perhatian sejak awal pembangunan. Padahal, seharusnya pengelolaan jangka panjang dan berkelanjutan harus menjadi perhatian saat fasilitas olahraga direncanakan untuk dibangun.

Sedangkan pada saat pengelolaan, terkait dengan biaya pengelolaannya, apabila mengharapkan pemasukan atau penerimaan dari pemanfaatan masyarakat atau pasar, maka pembangunan sejak awal harus mempertimbangkan keinginan masyarakat sebagai konsumen atau peluang pasar. Pengelolaan dengan Badan Layanan Umum dan Badan Usaha Milik Daerah akan sangat baik dalam kondisi tingkat partisipasi masyarakat yang tinggi dalam berolahraga, untuk itu harus sangat memperhatikan peluang pasar secara nyata. Terkait dengan lokasi pembangunan sarana dan prasarana olahraga tidak dibangun secara terpadu dengan pusat rekreasi lainnya seperti pusat kebudayaan dan pusat perbelanjaan sebagai daya tarik alternatif. Di samping itu, lokasi pembangunan juga mengabaikan persoalan aksesibilitas dan keterpaduan transportasi sehingga wajar apabila masyarakat kurang memanfaatkannya secara optimal.

Kemudian dari aspek output dan dampak dari pengelolaan sarana dan prasarana olahraga tersebut dalam peningkatan prestasi olahraga dan pembudayaan olahraga, kita dapat berkaca pada Kalimantan Timur, Riau, dan Sumatera Selatan, dapat diketahui bahwa ketersediaan sarana dan prasarana tidak ada hubungan yang kuat secara langsung dengan capaian prestasi olahraga begitu juga pembudayaan olahraga. Namun masih perlu dilakukan penelitian lebih lanjut bagaimana ketiga provinsi tersebut menyiapkan atletnya secara komprehensif, dan faktor-faktor yang mempengaruhi pembudayaan olahraga selain sarana dan prasarana.

Pengembangan dan pemanfaatan Sport Development Index (SDI) dapat menjadi referensi utama pembangunan fasilitas olahraga ke depan, agar fasilitas olahraga yang digunakan dapat bermanfaat secara optimal untuk keperluan peningkatan prestasi olahraga dan olahraga masyarakat dan rekreasi.

\section{Ucapan Terima Kasih}

Terima kasih kepada Bapak Nyoman Shuida selaku Deputi Bidang Koordinasi Revolusi Mental, Pemajuan Kebudayaan, dan Prestasi Olahraga Kemenko PMK, dan Bapak Gatot Hendrarto sebagai Asisten Deputi Bidang Peningkatan Prestasi Olahraga, atas kesempatan, dukungan, dan arahan, serta bimbingan kepada penulis untuk menyelesaikan penelitian ini. Penelitian ini merupakan penguatan aspek ilmiah dari penyiapan Rancangan Alternatif Kebijakan (RAK) bidang keolahragaan khususnya yang terkait dengan isu pengelolaan fasilitas olahraga, yang merupakan target output kinerja tahunan.

Secara khusus ucapan terima kasih juga kami sampaikan kepada Bapak Yuli Harsono, Deputi Bidang Pembangunan Manusia dan Kebudayaan, Sekretariat Kabinet, di mana pada tahap awal penelitian ini juga diinspirasi oleh penelitian beliau, tentang pengelolaan sarana dan prasarana olahraga pasca PON. Penelitiannya sempat dipaparkan dalam Focus Group Discussion bersama pemangku kepentingan terkait di pertengahan 2020 lalu. Dari hasil penelitiannya, memacu kami untuk mencari lebih dalam lagi dan melengkapinya dengan aspek ilmiah yang cukup.

Dari aspek teknis terkait penerbitan artikel penelitian ini, kami mengucapkan terima kasih yang sebesar-besarnya atas kesempatan publikasi yang diberikan dengan disediakannya wahana publikasi hasil penelitian oleh Bapak Satya Sananugraha, Sekretaris Kementerian Koordinator Bidang PMK, dan Bapak Sorni Paskah Daeli, Kepala Biro Hupok Kementerian Koordinator Bidang PMK, sehingga memacu kami sebagai Fungsional Analis Kebijakan untuk terus melakukan kajian-kajian ilmiah terkait penyelesaian Rancangan Alternatif Kebijakan.

\section{Referensi}

Badan Pusat Statistik-BPS. (2018). Statistik Sosial Budaya 2018. Badan Pusat Statistik-BPS. https://www.bps.go.id/publication/ $2019 / 07 / 05 / 153$ a 8 fecadb $642 f 5 c 4$ cf32e5/statistik-sosialbudaya-2018.html

Chen, Y. (2019). Research on Planning and Management of Large-Scale Sports Venues in Chinese Cities. Open House International, 44(3), 7679. https://doi.org/10.1108/OHI-03-2019-B0020

Fast Forward Advisors. (2018, Agustus 10). Sport Venue Management Innovations in Europe. Fast Forward Advisors. https:// fastforwardadvisors.com/news/sport-venue-management-innovationsin-europe/

Frey, J. H., \& Eitzen, D. S. (1991). Sport and Society. Annual Review of Sociology, 17(1), 503-522. https://doi.org/10.1146/ annurev.so.17.080191.002443 
Goslin, A. E., Sere, M. G. O., \& Kluka, D. A. (2015). Management capacity at sport and recreation facilities on local government level. African Journal for Physical, Health Education, Recreation and Dance, 21(4:1), 1290-1303. http://hdl.handle.net/2263/51456

Government of South Australia. (2018). Recreation \& Sport Facility Design Guide July 2018. Government of South Australia.

Harsono, Y. (2020). Pengelolaan Prasarana dan Sarana Olahraga Pasca Penyelenggaraan Pekan Olahraga Nasional. Setkab RI.

Hodgetts, D. J., \& Stolte, O. E. E. (2012). Case-based Research in Community and Social Psychology: Introduction to the Special Issue. Journal of Community \& Applied Social Psychology, 22(5), 379-389. https://doi.org/10.1002/casp.2124

Humphreys, C. (2019). The City of Sport: London's Stadiums as Visitor Attractions. In Destination London: The Expansion of the Visitor Economy (hal. 91-116). University of Westminster Press. https:/l doi.org/10.16997/book35.e

Hutchinson, M., Berg, B. K., \& Kellison, T. B. (2018). Political activity in escalation of commitment: Sport facility funding and government decision making in the United States. Sport Management Review, 21(3), 263-278. https://doi.org/10.1016/j.smr.2017.07.005

Iversen, E. B., \& Cuskelly, G. (2015). Effects of different policy approaches on sport facility utilisation strategies. Sport Management Review, 18(4), 529-541. https://doi.org/10.1016/j.smr.2014.12.004

Jakar, G. S. (2020). Private and Public Sports Venue Development Dilemmas: Economic Geography, Sport Venue Development, and Public Finance [University of Michigan]. https://hdl.handle.net 2027.42/163045

Kristiyanto, A. (2012). Pembangunan Olahraga untuk Kesejahteraan Rakyat dan Kejayaan Bangsa. Yuma Pustaka.

Kruszyńska, E., Jančoková, L'., \& Sieńko-Awierianów, E. (2018). Functioning of sport and recreation facilities of the city of Poznan in the opinion of service providers. Ekonomiczne Problemy Turystyki, 44(44), 157-167. https://doi.org/10.18276/ept.2018.4.44-13

Kurniantyo, F. G. Y. (2015). Hubungan Antara Fasilitas dan KBM Olahraga dengan Perilaku Hidup Sehat Mahasiswa FKIP Universitas Kristen Satya Wacana Salatiga Tahun 2013. Active: Journal of Physical Education, Sport, Health and Recreation, 4(5), 1832-1838. https:/ doi.org/10.15294/active.v4i5.5470

Lee, S. "Shawn," Parrish, C., \& Kim, J.-H. (2015). Sports Stadiums as Meeting and Corporate/Social Event Venues: A Perspective From Meeting/Event Planners and Sport Facility Administrators. Journal of Quality Assurance in Hospitality \& Tourism, 16(2), 164-180. https:/ doi.org/10.1080/1528008X.2015.1013406
Levermore, R. (2015). Sport in international development: Facilitating improved standard of living? In B. Houlihan \& M. Green (Ed.) Routledge Handbook of Sports Development (hal. 55-66). Routledge.

Mulyo, S., Kristiyanto, A., \& Kiyatno. (2014). Kebijakan Pemerintah Tentang Penyediaan Fasilitas Olahraga Pendidikan di SMP Se-kabupaten Demak (Analisis Tentang Prosedur, Pemerataan, Ketersediaan, dan Ketercukupan Fasilitas Olahraga Pendidikan). Indonesian Journal of Sports Science, 1(1), 1-11.

Mutohir, T. C., \& Maksum, A. (2007). Sport Development Index: Alternatif Baru Mengukur Kemajuan Pembangunan Bidang Keolahragaan (Konsep, Metodologi, dan Aplikasi). Bessindo Primalaras.

Neuman, W. L. (2014). Social Research Methods: Qualitative and Quantitative Approaches (7 ed.). Pearson New International Edition.

Patrian, P., Hidasari, F. P., \& Haetami, M. (2018). Evaluasi Sarana dan Prasarana Olahraga Jurusan IImu Keolahragaan Prodi Penjaskesrek Universitas Tanjungpura. Jurnal Pendidikan dan Pembelajaran Khatulistiwa, 7(7), 1-15. https://jurnal.untan.ac.id/index.php/jpdpb/ article/view/26725

Prastio, A. (2014). Profil Lamongan Sports Center (LSC) Ditinjau dari Segi Managemen, Fasilitas dan Pelayanan. Jurnal Kesehatan Olahraga, 2(3), 1-9. https://jurnalmahasiswa.unesa.ac.id/index.php/jurnalkesehatan-olahraga/article/view/8478

Prihatin, E. (2011). Teori Administrasi Pendidikan. Alfabeta

Rismayanthi, C. (2007). The Sport Facilities Management in the Sport Industry. In Universitas Negeri Yogyakarta (hal. 1-12).

Riyes, I. (2015). Pengelolaan Sarana dan Prasarana Olahraga pada Sekolah Penyelenggara Kelas Khusus Olahraga (KKO) di SMP Negeri 3 Sleman Kabupaten Sleman Daerah Istimewa Yogyakarta [Universitas Negeri Yogyakarta]. http://eprints.uny.ac.id/id/eprint/28984

Schwarz, E. C., Hall, S. A., \& Shibli, S. (2019). Sport Facility Operations Management. In Sport Facility Operations Management. Routledge. https://doi.org/10.4324/9780429026102

Sport New Zealand. (2017). Sport \& Recreation Facility Development Guide Sport New Zealand.

Sujana, D. (2018). The Influence of Infrastructure Management on Sports Development at State Polytechnics in Bandung. Soshum: Jurnal Sosial dan Humaniora, 8(1), 23-32. https://doi.org/10.31940/ soshum.v8i1.795

Sun, Z. (2015). A Brief Analysis of Sports Venues in Colleges and Universities. Asian Social Science, 11(16), 114-117. https://doi.org/ 10.5539/ass.v11n16p114

Wilson, R. D., \& Creswell, J. W. (1996). Research Design: Qualitative and Quantitative Approaches. Journal of Marketing Research, 33(2), 252. https://doi.org/10.2307/3152153 